\title{
КАДРЫ ДЛЯ ЦИФРОВОЙ ЭКОНОМИКИ. ЦИФРОВИЗАЦИЯ ОБРАЗОВАНИЯ. ЦИФРОВАЯ ГРАМОТНОСТЬ
}

\author{
(C) 2020 Строков Алексей Александрович \\ старший преподаватель-методист отделения методического \\ обеспечения учебного процесса учебного отдела \\ Нижегородская академия МВД России, Россия, Нижний Новгород \\ E-mail: strokoff@list.ru
}

В статье анализируются вопросы совершенствования системы высшего образования и подготовки кадров для цифровой экономики РФ.

Ключевые слова: система образования, цифровая экономика, компетентные кадры, цифровизация образования, цифровые компетенции, цифровая грамотность.

Актуальность данного исследования обусловлена особой ролью образования в жизни современного общества. Активизация экономических и социальных программ кардинально изменяет общественное устройство, запуская инновационные технологические и образовательные процессы.

Одним из долгосрочных проектов нашего государства, затрагивающим все направления современного развития, стала Национальная программа «Цифровая экономика Российской Федерации» (далее - «Цифровая экономика») которая направлена прежде всего на «создание условий для развития общества знаний, повышение благосостояния и качества жизни граждан путем повышения доступности и качества товаров и услуг, произведенных в цифровой экономике с использованием современных цифровых технологий, повышения степени информированности и цифровой грамотности, улучшения доступности и качества государственных услуг для граждан, а также безопасности как внутри страны, так и за ее пределами» [1].

Успешное функционирование и развитие «Цифровой экономики» невозможно без людей, обладающих высоким уровнем цифровой грамотности. При этом цифровая грамотность не является свойством, стихийно приобретаемым человеком, рожденным в эпоху цифровизации. Это система знаний, навыков и установок, насущно необходимых для жизни в цифровом обществе, их формирование и развитие должно быть осознанным и управляемым, и только при этом условии возможно достижение главной цели цифровизации - повышения качества жизни людей [2].
Образовательный процесс построен на реализации образовательных стандартов, однако «логика компетентностного подхода в образовательных стандартах означает, что обучающиеся должны сознательно взять на себя ответственность за собственное обучение. Необходимость отказа от практики простой ретрансляции знаний диктует потребность создания механизма освоения обучающимися процессов поиска, обработки и использования информации» $[3,1573]$.

Полагаем, что процесс цифровизации образования неминуемо должен привести к изменению образовательных стандартов, в том числе включения цифровых компетенций, которые будут определять цифровую деятельность, как раздел требований предъявляемый к результатам освоения для отдельно взятой образовательной программы.

Цифровые компетенции должны включать в себя способность к цифровому сотрудничеству, обеспечению кибербезопасности, усовершенствованию подходов к цифровой грамотности и решению образующихся информационнокоммуникационных потребностей социума.

При активизации технологичности образования остается открытым вопрос о цифровой грамотности участников образовательных отношений как неотъемлемом этапе реализации компетентностного подхода.

Цифровая грамотность - это способность человека использовать цифровые инструменты (в самом широком смысле) с пользой для себя. Для высококвалифицированного специалиста необходимо уметь читать с экрана цифрового устройства и усваивать эту информацию, применять различные цифровые инструменты для 
повышения эффективности своего труда, применять облачные технологии для работы в любом месте и в любое время [4].

Думается, что при формировании цифровой грамотности у обучающихся, как одного из этапов формирования цифровых компетенций, необходимо применение междисциплинарных связей, не ограничивая их изучением дисциплин «Основ информационной безопасности», «Информатики и информационных технологий».

Для идентификации усвоения компетенций особое внимание должно быть уделено и цифровой грамотности педагогических работников, которая должна включать в себя не только знания образовательной политики, но и инновации в цифровом образовании.

Подводя итоги исследованию, полагаем, что образовательные организации в ситуации с развитием «Цифровой экономики» не должны отставать от цифровых технологий, а активно включаться в процесс подготовки кадров. Однако данный процесс не будет возможным, если не будут сделаны встречные шаги со стороны Министерства образования РФ, при разработке образовательных стандартов учитывающих особенность подготовки востребованного специалиста нового цифрового поколения, а также налажено финансирование и закупка высокотехнологичного оборудования для реализации образовательного процесса.

\section{Библиографический список}

1. Программа «Цифровая экономика Российской Федерации» // Сайт Правительства РФ, 28.07.2018 (http:// pravo.gov.ru/proxy/ips/?docbody=\&nd=102440918 дата обращения к ждокументу 9.06.2020)

2. OECD Digital Economy Outlook, 2017 (https://www.oecd.org/internet/oecd-digital-economy-outlook-20179789264276284-en.htm дата обращения к документу: 10.06.2020)

3. Batova M.M. (2019) Formirovanie tsifrovyh kompetentsiy v sisteme «obrazovanie - nauka - proizvodstvo» [Formation of digital competencies in the system "education - science - production"].Voprosy innovatsi-onnoy ekonomiki. 9. (4).-1573-1584

4. Берман Н.Д. К вопросу о цифровой грамотности (https://cyberleninka.ru/article/n/k-voprosu-o-tsifrovoygramotnosti дата обращения к документу: 10.06.2020) 